\title{
PERAN KIAI HAJI IRFAN HIELMY DALAM MENGEMBANGKAN DUNIA PENDIDIKAN DAN DAKWAH DI KABUPATEN CIAMISJAWA BARAT (1933-2010)
}

\author{
Elah Nurhasanah \\ Miftahul Huda Al-Azhar (STAIMA) Kota Banjar \\ Nahla.banjar29@gmail.com
}

\begin{abstract}
The development of Islam specifically in the world of da'wah and education in the Ciamis area is inseparable from the role of the kiai or community leaders in the area. One of the figures of many kiai is Kiai Haji Irfan Hielmy, who is supported in Dewasari Village, Dewasari Village, Cijeungjing District, Ciamis Regency, West Java. Seeing so the contribution of Irfan Hielmy to the development of Islam in Ciamis, then there was an interest in studying the figure as one of the links in the development of Islam in Indonesia specifically in the field of Islamic education and propaganda. In the world of education, Irfan Hielmy always asks his students to study anywhere in order to have broad insights. Making his students as moderate Muslims, democratic believers, and diplomatic muhsin. His da'wah activity is the implementation of amar ma'ruf nahi munkar. Irfan Hielmy which is applied to the students and the community in Ciamis Regency, has a great influence on people's lives. His da'wah activity is the implementation of amar ma'ruf nahi munkar.
\end{abstract}

Keywords: Irfan Hielmy, Da'wah, Education

\begin{abstract}
Abstrak
Perkembangan Agama Islam khususnya dalam dunia dakwah dan pendidikan di daerah Ciamis tidak terlepas dari peran para kiai atau tokoh masyarakat yang ada di daerah tersebut. Salah satu figur dari


sekian banyak kiai adalah Kiai Haji Irfan Hielmy yang dilahirkan di Kampung Dewasari Desa Dewasari Kecamatan Cijeungjing Kabupaten Ciamis, Jawa Barat. Melihat begitu besarnya sumbangan Irfan Hielmy terhadap perkembangan agama Islam di Ciamis maka kemudian ada ketertarikan untuk mengkaji tokoh tersebut sebagai salah satu mata rantai perkembangan Islam di Indonesia khususnya dalam bidang pendidikan dan dakwah Islam. Dalam dunia pendidikan, Irfan Hielmy selalu menekankan kepada para santrinya untuk menuntut ilmu dimanapun agar memiliki wawasan yang luas. Menjadikan para santrinya sebagai muslim yang moderat, mukmin yang demokrat, dan muhsin yang diplomat. Aktivitas dakwahnya merupakan implementasi amar ma'ruf nahi munkar. Pemikiran-pemikiran Irfan Hielmy yang diterapkan kepada para santri dan masyarakat di Kabupaten Ciamis, mempunyai pengaruh yang besar dalam kehidupan di masyarakat. Aktivitas dakwahnya merupakan implementasi amar ma'ruf nahi munkar.

Kata Kunci: Irfan Hielmy, Dakwah, Pendidikan

\section{PENDAHULUAN}

Salah satu figur dari sekian banyak kiai adalah Kiai Haji Irfan Hielmy yang dilahirkan di Kampung Dewasari Desa Dewasari Kecamatan Cijeungjing Kabupaten Ciamis, Jawa Barat. Ia melanjutkan memimpin pondok pesantren di Dewasari dengan Nama Ponduk Pesantren Darussalam kemudian ia dikenal sebagai kiai.

Semenjak belajar di sekolah rakyat (Vervolg School) kiai Irfan Hielmy sudah belajar bahasa Belanda kepada kakek dari keluarga ibunya. Setelah itu dia melanjutkan pendidikannya ke pesantren Cikalong Tasikmalaya dan ke pesantren Panyawungan Desa Cileunyi Kecamatan Rancaekek Kabupaten Bandung selama 4 tahun lamanya. Di pesantren inilah Irfan Hielmy belajar ilmu Mantiq dan ilmu Munadlarah (metode debat/diskusi) kepada K.H. Kholil.

Sebagai orang santri yang cerdas dan tekun belajar maka Irfan Hielmy dapat menguasai kitab-kitab seperti kitab Balaghah yaitu Jauharul Maknum, Uqudul Juman, Talkhisul Miftah, berikut syair- 
syairnya. Keahlian atau spesialisasinya adalah ilmu Nahwu, ilmu Sharaf, ilmu Balaghah, ilmu Mantiq, ilmu Mudalarah dan ilmu Tafsir.

Peranan Kiai Haji Irfan Hielmy dalam mengembangkan agama Islam terbukti dalam bidang pendidikan dan dakwah Islamiyah. Di bidang pendidikan kiai Irfan Hielmy dapat mengembangkan Pondok Pesantren Darussalam sejak tahun 1930 dan mampu bertahan sampai sekarang. Dengan adanya Pondok Pesantren ini maka perkembangan pendidikan Islam di Cijeungjing bertambah pesat. Hal ini terbukti dengan banyaknya santri yang masuk yaitu sekitar 2000 orang dalam waktu lima tahun. Selain itu pada tahapan awal Irfan Hielmy mendirikan madrasah di pesantren, seperti Madrasah Diniyah Darussalam ditambah dengan kursus bahasa Belanda serta mendirikan organisasi pendidikan guru Islam bersama tokoh lainnya seperti K.H. A. Junaedi, kiai Syafi'i, K.H. M. Yusuf Shiddieq, kiai Ahmad Huzaeri, K.H. Muh. Yacub Syarwani dan K.H. A. Iskandar serta para kiai dari berbagai pesantren di daerah Ciamis, pada tahun 1948.

Selain itu, ia mendidik masyarakat melalui pembinaan mental. Hal ini ditanamkan agar ummat Islam pada umumnya memiliki sikap dan motivasi yang kuat dalam menghadapi penjajah sehingga pantang menyerah. Selain itu kiai Irfan Hielmymembentuk Majelis Taklim, kelompok-kelompok pengajian dan menghadiri berbagai pengajian di luar daerah.

Di bidang dakwah islamiyah, ia berdakwah melalui organisasi politik (Masyumi). Semasa revolusi bangsa Indonesia, ia mempunyai andil di dalam mempertahankan kemerdekaan Republik Indonesia hingga akhirnya ia meninggal dunia pada tahun 2010.

Melihat begitu besarnya sumbangan Irfan Hielmy terhadap perkembangan agama Islam di Ciamis maka kemudian ada ketertarikan untuk mengkaji tokoh tersebut sebagai salah satu mata rantai perkembangan Islam di Indonesia khususnya dalam bidang pendidikan dan dakwah Islam.

\section{METODE}

Metode yang digunakan adalah Metodologi sejarah, yakni merupakan suatu prosedur atau metode yang digunakan untuk tahu 
bagaimana mengetahui. Dalam penelitian ini, langkah yang ditempuh meliputi empat kegiatan pokok, sebagai berikut: 1. Heuristik adalah kegiatan mencari dan menemukan sumber yang diperlukan. Berhasiltidaknya pencarian sumber, pada dasarnya tergantung dari wawasan peneliti mengenai sumber yang diperlukan dan keterampilan teknis penelusuran sumber. Berdasarkan bentuk penyajiannya, sumber-sumber sejarah terdiri atas arsip, dokumen, buku, majalah/jurnal, surat kabar, dan lain-lain. Berdasarkan sifatnya, sumber sejarah terdiri atas sumber primer dan sumber sekunder. Sumber primer adalah sumber yang waktu pembuatannya tidak jauh dari waktu peristiwa terjadi. Sumber sekunder adalah sumber yang waktu pembuatannya jauh dari waktu terjadinya peristiwa. Peneliti harus mengetahui benar, mana sumber primer dan mana sumber sekunder. Dalam pencarian sumber sejarah, sumber primer harus ditemukan, karena penulisan sejarah ilmiah tidak ukup hanya menggunakan sumber sekunder. 2. Kritik, yaitu menyeleksi sumber yang meliputi dua aktifitas sebagai berikut: Kritik ekstern adalah meneliti outentisitas sumber. Untuk meneliti outentisitas sumber yang telah diperoleh, dilakukan evaluasi, baik terhadap sumber primer maupun sumber sekunder dengan cara menyelidiki outentisitasnya, sehingga diperoleh sumber yang akurat. Kritik Intern adalah meneliti kebenaran isi sumber. Dalam meneliti kebenaran isi sumber, digunakan cara yaitu: meneliti bahasa yang dipakai, integritas pribadi dan tujuan tulisan. Meneliti tokoh-tokoh yang mengalami peristiwa, baik tokoh utama maupun pengikutnya atau orang yang mendengar langsung dari saksi pertama. 3. Interpretasi yaitu penafsiran atas sumber yang telah diseleksi melalui kritik yang tersusun menjadi fakta sejarah. Untuk menginterpretasikan fakta yang telah diperoleh, digunakan pendekatan sosio kultural, yaitu sebagai alat untuk menganalisa kondisi sosial dan kultur dimana tokoh itu dibesarkan, bagaimana proses pendidikan formal dan informal yang dialami serta bagaimana watak-watak orang ada di sekitarnya. 4. Historiografi, yaitu penyusunan kesaksian yang dapat dipercaya menjadi kisah atau penyajian yang berarti. Dalam skripsi ini, disajikan karya ilmiah yang berbentuk deskriftif analitis. Menulis sejarah merupakan suatu kegiatan intelektual dan ini suatu ara yang utama untuk memahami sejarah 


\section{PEMBAHASAN}

Irfan Hielmy dilahirkan pada tanggal 25 Desember 1933 di sebuah Dusun Kandang Gajah, Desa Dewasari, Kecamatan Cijeungjing, Kabupaten Ciamis Jawa Barat. Ia anak dari delapan bersaudara, dari pasangan Ahmad Fadlil dan Siti Maemunah. Ahmad Fadlil adalah seorang tokoh yang mendirikan Pondok Pesantren Cidewa (cikal bakal Pondok Pesantren Darussalam).

Dari 8 anak itu hanya Irfan Hielmy yang dapat meneruskan citacita Ahmad Fadlil. Secara formal, pendidikan Irfan Hielmy hanya sampai di sekolah dagang (setingkat SLTP sekarang) di Kota Tasikmalaya. Irfan Hielmy menikah pada tahun 1955 dengan seorang gadis yang bernama Yuyu Dayu Robi'ah Adawiyah. Perkawinan mereka melahirkan 6 orang anak. Irfan hielmy juga pernah minimba ilmu di Pondok Pesantren Darussalam Gontor. Meskipun tidak begitu lama di pesantren ini, namun kesan selama disana begitu mendalam, sehingga meneruskan ayahandanya sebagai pengasuh pesantren, ia mengubah nama "Pesantren Cidewa" menjadi "Pesantren Darussalam".

Pada yahun 1951-1952 ia menjadi guru sekolah Rakyat Kertaharja II. Atas kehendak pamannya, Ajengan Sahori (kakak Ahmad Fadlil) agar memimpin pesantren, maka ia berhenti menjadi guru Sekolah Rakyat. Pada tahun 1953-2954 organisasi Muhammadiyah membuka PGA di Ciamis (sekarang menjadi AKPER) kemudian ia menjadi guru disana. Kemudian tahun 1968-1970 ia diangkat menjadi pemilik Depag yang membawahi daerah Cijeungjing. Setelah itu ia menjadi kepala MAN Darussalam pada tahun 1970-1972.

Kegigihan ayahnya lewat Masyumi ini, kemudian menurun kepada Irfan Hielmy. Pada masa mudanya, ia aktif di Masyumi. Ia juga pernag menjabat sebagai ketua PII (Pelajar Islam Indonesia) Ciamis yang pertama kali dan pernah mengikuti Muktamar PII di Yogyakarta. Ia juga pernah mengikuti kongres PUI, NU, sewaktu masih ngajar di PGA. PII berdiri pada tanggal 4 Mei 1977. tujuan PII adalah menyatukan pelajar-pelajar Islam dalam suatu wadah ajaran-ajaran Islam serta mendidik anggotanya untuk mengamalkan ajaran-ajaran Islam secara kaffah, sesuai dengan tuntutan syariah Islam dengan berpedoman pada al Quran dan Hadist. 
Organisasi yang pernah ia masuki bukan hanya itu saja, sejak tahun 1997 ia mulai karirnya dalam politik dengan memilih organisasi Golkar sebagai wadah perjuangannya. Perkenalannya dengan Golkar berawal dari statusnya sebagai pegawai negeri. Pada saat itu ada semacam keharusan bahwa PNS harus masuk Golkar. Puncak karirnya di Golkar yaitu menjadi anggota MPR pada tahun 1997, sebagai wakil golongan ulama dan kyai di Provinsi Jawa Barat. Namun ia duduk di kursi MPR tidak begitu lama. Hal itu dikarenakan ada gerakan reformasi yang dimotori oleh para mahasiswa dan elit politik untuk merubah system yang ada. Kemudian dari sejak tahun 1998 ia menjabat sebagai dewan penasehat Golkar Kabupaten Ciamis.

Pada tahun 1998 ia menjadi ketua MUI Kabupaten Ciamis. Dari MUI inilah kemudian namanya cepat dikenal. Hal ini karena kearifan dan kebijaksanaannya serta menjadi seorang pigur para kyai di Kabupaten Ciamis. Selama berkiprah di MUI, ia selalu menekankan pelaksanaan hukum Syariat. Dari pemikiran-pemikirannya selama di MUI terlihat bahwa ia termasuk orang yang sangat keras dalam masalah hukum Islam. Pernah suatu ketika Kepala Desa Cijulang tersebut meminta surat rekomendasi dan minta tanda tangan Irfan Hielmy, akan tetapi Irfan Hielmy langsung mengirim surat balasan kepada Kepala Desa tersebut yang isinya tidak mau menandatangani surat tersebut, karena thariqat tersebut bersebrangan dengan hukum Islam.

K.H. Irfan Hielmy, Pengasuh Pondok Pesantren Darussalam CiamisJawa BaratIndonesia, wafat, Selasa, 04 Jumaadil Awwal 1431 Hijriyah/ 18 Mei 2010, pukul 06:00 WIB di kediaman putra ketiganya K.H. Dr. Fadlil Yani Ainusyamsi, MBA., M.Ag. Kepergian almarhum untuk selama-lamanya menyisakan tangis bagi ribuan santri, alumni, dan warga Ciamis yang memadati kompleks Pondok Pesantren Darussalam waktu itu. Sebelum kepergiannya, almarhum sempat dirawat di berbagai rumah sakit yang berbeda. Dia pernah dirawat di RSHS Bandung karena penyakit liver. Sejak lama dia memang mengidap penyakit liver dan gangguan pencernaan lain. Bahkan sebelum kepergiannya, dia juga sempat dirawat di rumah sakit di Tasikmalaya 
Irfan hielmy mulai terjun dalam dunia Pendidikan dimulai tahun 1960. ia menggantikan ayahnya sebagai pengasuh Pondok Pesantren Darussalam Ciamis. Sedikit demi sedikit ia terus mengembangkan berbagai sarana dan fasilitas pendidikan yang diperlukan santri. Ia bertekad untuk merintis kembali berdirinya pesantren yang baru dengan corak "Pembaru". Inisiatif ini diambil dengan alasan untuk dapat meneruskan perjuangan Islam. Satu hal yang acap dikenang oleh alumni Pesantren Darussalam adalah kebersahajaan pesantren ini dalam keseharian santrinya. Bahkan, seperti yang kerap terucap dari K.H. Irfan Hielmy pendiri Pondok Pesantren Moderen Darussalam yang selalu mengajarkan kebersahajaan setiap kali menerima kunjungan tamu, selalu disambut dengan kalimat yang sama, seolah menegaskan bagaimana seharusnya santri Darussalam mengambil posisi dengan kerendah-hatian, "selamat datang di tempat kami, pesantren yang sangat sederhana."

Ihwal kebersahajaan dan kesederhanaan Darussalam ternyata sama tuanya dengan sejarah pesantren ini. Pada tahun 1929, K.H. Ahmad Fadlil (wafat th. 1950), ayahanda K.H. Irfan Hielmy, memulai kisah kebersahajaan dengan sebuah masjid dan sebuah bilik sebagai asrama. Santri yang pertama kali mondok adalah pemuda-pemuda setempat yang tidak hanya diajari ilmu-ilmu agama, akan tetapi diajak mengolah sawah, bercocok tanam dan diberi contoh bagaimana memelihara bilik dan memakmurkan masjid. Pesantren Cidewa, sebutan untuk komunitas baru itu, dengan cepat mendapat simpati serta dukungan dari masyarakat sekitar dan lebih banyak lagi santri yang mondok.

Adalah suami-istri Mas Astapradja dan Siti Hasanah yang mewakafkan tanahnya di Kampung Kandanggajah, Desa Dewasari, KecamatanCijeungjing, KabupatenCiamisJawa Barat kepada K.H. Ahmad Fadlil. Dibantu oleh masyarakat dan santri, Pesantren Cidewa menapaki guratan sejarah dengan optimisme menghilangkan benalu yang menempel dalam ajaran Islam.

Menjelang proklamasi kemerdekaan 17 Agustus 1945, di Pesantren Cidewa sudah mondok 400 orang santri yang mengaji ilmu tafsir, ilmu hadits, sejarah dan perbandingan madzhab, di samping 
kitab-kitab ilmu sharaf dan ilmu nahwu. Keputusan K.H. Ahmad Fadlil dengan hanya menerima santri putra tidak terlepas dari kondisi saat itu yang tidak bisa terlepas dari kontelasi keamanan akibat penjajahan Belanda. Akan tetapi karena didorong oleh keinginan untuk melepaskan diri dari cengkraman penjajah dan ditambah dengan meluapnya semangat santri untuk menghalau Belanda, K.H. Ahmad Fadlil juga mengajarkan strategi berdiplomasi mengatasi tekanan penjajah. Apalagi dengan kemampuannya berbahasa Belanda yang didapat dari kakeknya sejak di Sekolah Rakyat (Vervolg School)- dengan mudah bisa menyerap berbagai informasi yang kelak berguna sebagai modal berdiplomasi.

Lebih dari itu, penguasaan terhadap teks berbahasa Arab telah tampak sejak Ahmad Fadlil muda berhasil menghapalkan kitab-kitab seperti Jauharul Maknun, 'Uqudul Juman, Talkhisul Miftah dan syairsyair nya. Bahkan, pada usia 31 tahun ia telah berhasil menerjemahkan Qashidah Burdah karya Muhammad Said al-Busyiri. Sampai sekarang, Qashidah Burdah berbahasa sunda yang merupakan karya terjemahan masterpiece K.H. Ahmad Fadlil masih terdengar dibaca dan didendangkan oleh santri-santri di banyak pesantren tradisional terutama di Jawa Barat.

Melalui sejarah yang panjang (berdiri tahun 1929 oleh K.H. Ahmad Fadlil), kini Pondok Pesantren Darussalam telah berkembang dan mencapai kemajuan yang sangat menggembirakan. Pondok Pesantren yang pada awal berdirinya hanya memiliki sebuah rumah tempat tinggal Kiayi, sebuah masjid dan sebuah asrama (pondok) yang sederhana, kini telah memiliki fasilitas bangunan yang relatif lengkap dan beberapa di antaranya cukup megah.

Disamping peningkatan fasilitas dan sarana pendidikan untuk santri, hal yang sangat penting lain adalah pengembangan sistem pendidikannya. Ketika di banyak Pondok Pesantren lain masih mengkhususkan pada pengajian kitab, Pesantren Darussalam mulai merintis untuk menyelenggarakan pendidikan formal. Maka sejak dasawarsa 60-an, Pesantren Darussalam mulai memodernisasikan sistem pendidikannya dengan mendirikan lembaga-lembaga pendidikan formal. 
Visi yang ia lakukan dalam peningkatan kualitas pendidikan Pondok Pesantren Darussalam yaitu membangun system pendidikan pesantren modern yang mengarqah kepada terwujudnya kehidupan masyarakat beradab dan berakhlak serta menjungjung tinggi prinsipprinsip kebenaran dan keadilan. Membangun alumni pesantren yang memiliki jiwa demokratis, kritis dan intelektual dengan mengedepankan wacana akademik dan kearifan sikap dalam memecahkan berbagai masalah keagamaan dan kemasyarakatan. Serta aktif menaggulngi persoalan yang timbul dalam kehidupan bangsa dan Negara, membangun persaudaraan antar santri dengan berbagi komponen bangsa yang majemuk. Serta menjalin kerjasama yang saling menguntungkan dan saling mengokohkan dalam pergaulan kebangsaan.

Dalam menjalankan roda pesantren Darussalam dan menanamkan kedisiplinan sebagai identitas menghadapi santri-santrinya ia membuat motto sekaligus sebagai tujuan pendidikan, yakni membentuk muslim yang moderat, mukmin yang demokrat, dan muhsin diplomat. Muslim moderat adalah sosok pribadi muslim yang memiliki keluwesan, tenggang rasa, memiliki solodaritas social, menghormati orang lain, menghindari sikap angkuh dan eksterm, serta tidak ingin menang sendiri. Dari sinilah santri dituntut untuk bersikap toleran terhadap perbedaan pendapat dengan siapapun, menghargai pemikiran orang lain dan tidak mkemaksakan kehendak kepada orang lain. Dalam masalah-masalah akidah dan ibadah mahdah, santri dididik agar kuat memegang dan mengikuti ajaran yang telah dicontohkan Rosululloh SAW.

Mukmin demikrat adalah sosok manusia yang pikiran dan perilakunya berjiwa demokratis. Ia bersifat responsive terhadap aspirasi dan keluhan masyarakat, apresiatif terhadap pandangan masyarakat, mengayomi masyarakat, terbuka kepemimpinannya, memperhatikan pengkaderan generasi penerus, memiliki banyak inisiatif dan kreatif dalam memajukan masyarakat. Muhsin diplomat adalah pribadi yang gemar melakukan kebaikan dan kesalihan, bersikap piawai, santun, halus lembut, dan berbudi luhur dalam bergaul dengan siapa saja.

Pada tahun 1967, mulai dirintis penyelenggaraan sistem pendidikan modern dengan mengadaptasi model klasikal dan sampai 
saat ini semua jenjang pendidikan dar mulai Taman Kanak-kanak (TK) (di Pesantren Darussalam disebut Raudlatul Athfal/RA) hingga perguruan tinggi telah ada di pesantren ini.

Lembaga pendidikan formal yang pertama didirikan adalah Raudlatul Athfal (Taman Kanak-kanak) pada tahun 1967, kemudian pada tahun 1968 berdiri Madrasah Ibtidaiyah/MI (setingkat SD), lalu Madrasah Tsanawiyah Darussalam/MTsD (setingkat SMP) pada tahun 1968. kemudian berdiri Madrasah Aliyah Negeri Darussalam (setingkat SMA) pada tahun 1969. Pada tahun 1987 Pesantren Darussalam mendapatkan kepercayaan dari Pemerintah Republik Indonesia melalui menteri agama RI (waktu dijabat oleh Munawir Sadzali) untuk menyelenggarakan Madrasah Aliyah Program Khusus (MAPK). MAPK Darussalam merupakan satu dari lima MAPK di seluruh Indonesia yang peresmiannya secara nasional dipusatkan di Pesantren Darussalam. Dalam perjalanannya, pada tahun 1992 MAPK mengalami perug \bahan nama menjadi Madrasah Aliyah Keagamaan Negeri (MAKN).

Selanjutnya didirikan SMA Plus Darussalam yang merupakan lembaga pendidikan swasta pada tahun 2003. Sedangkan Pendidikan Tinggi (PT) di Pondok Pesantren Darussalam adalah berbentuk Institut yang didirikan pada tahun 1970, dengan nama Institut Agama Islam Darussalam Ciamis (IAID) yaitu Perguruan Tinggi Agama Islam yang menggabungkan pendidikan akademik dengan pendidikan kepesantrenan, yaitu Pondok Pesantren Darussalam. Disamping itu, pada tahun 1995 diselenggarakan pula Ma'had 'Aly, yaitu pendidikan tinggi Pesantren Darussalam. Mahasantri Ma'had 'Aly ini terdiri dari lulusan Madrasah Aliyah dan para mahasiswa Institut Agama Islam Darussalam dari berbagai fakultas yang memenuhi persyaratan, di antaranya telah mampu membaca kitab-kitab kuning.

Pada tahun akademik 1995/1996 IAID menyelenggarakan enam jurusan, yaitu Fakultas Syariah terdiri dari jurusan Ahwal asSyakhsyiyyah (AS) dan jurusan Jinayah Siyasah (JS), fakultas Tarbiyah terdiri dari jurusan Bahasa Arab (BA) dan jurusan Kependidikan Islam (KI), sedangkan fakultas Usluhudin diganti dengan fakultas Dakwah yang terdiri dari jurusan Komunikasi dan Penyiaran Islam (KPI) dan jurusan Bimbingan dan Penyukuhan Islam (BPI) (Selayang pandang 
Pesantren Darussalam: 3). Pada tahun 1995 Institut Agama Islam Darussalam telah mewisuda 380 orang lulusan S-1 sedangkan alumni sarjana semua telah mencapai 840 orang Sarjana Muda. Puncak karirnya dalam dunia pendidikan ia menjadi rektor di IAID Ciamis. Berikut adalah riwayat pekerjaan yang pernah diembannya:

1. Guru PGA Muhammadiyah (1953 - 1954);

2. Guru SMP PUI Cijantung (1954-1956);

3. Penilik MI se-Kabupaten Ciamis (1960-an)

4. kepala sekolah SD PUI Dewasari (1957-1964);

5. Pembantu Imam Militer (1957-1963);

6. Roh Res Kepolisian 845 Ciamis (1966-1972)

7. Anggota DPRDKabupatenCiamis (1967-1972)

8. Kepala Sekolah MAN Darussalam Ciamis (1968-1993);

9. Dekan Fakultas Syariah Darussalam Ciamis (1970-1973);

10. Ketua Staf Pengkaderan Dakwah MUIJawa Barat (1992-1995)

11. Rektor Institut Agama Islam Darussalam Ciamis (1973-1999)

12. Anggota MPR RI (1997-1999)

13. Ketua Umum MUI Kabupaten Ciamis (1998-2010)

Karya tulis yang pernah dibuat:

1. Bunga Rampai menuju Khairu Ummah (1994.

2. Dakwah bi al-Hikmah (1997).

3. Kumpulan Materi Pokok Khutbah Jum'at (1997).

4. Masyarakat Madani: Suatu Ikhtiar Dalam Menyongsong Era Milenium Baru (1998.)

5. Pendekatan Keagamaan Dalam Menyelesaikan Masalah Kemasyarakatan (1998).

6. Ukhuwwah Ahlus Sunnah: Khazanah Aqidah, Moral dan Spiritual dari Pesantren (1999)

7. Pesan Moral dari Pesantren (1999).

8. Wacana Islam, Bahan Telaah Anak Bangsa (2000.)

9. Sentuhan Wahyu, Penyejuk Kalbu (2003), dan lain-lain.

Dalam proses kegiatan dakwah, Irfan Hielmy sebagai mahluk social tidak terlepas dari pengaruh sosio-kultural dimana ia hidup, sehingga perkembangan hidup dan tingkah lakunya pun tidak terlepas dari lingkungan sekitarnya. Dalam berdakwah, prinsip umum yang 
dipegang oleh Irfan Hielmy sama dengan para da'i yang lainnya, yaitu menjalankan amar ma'ruf nahi munkar. Irfan Hielmy dalam melakukan dakwahnya selalu memakai konsep yang bijaksana. Artinya, dakwah yang dilakukan tidak dipaksakan kepada masyarakat. Masyarakat diberikan pengertian secara berangsur-angsur dan pelan-pelan. Dakwah secara komperhenshif yang dilakukan oleh Irfan Hielmy tersebut mengalami proses yang panjang. Selama ia berdakwah, baru 30 tahun kemudian masyarakat mau menerima pemikirannya.

Awal pemikiran Irfan Hielmy adalah melalui tafsir yang diajarkan pada santri-santrinya. Dengan belajar tafsir ditanamkan oleh Irfan Hielmy pada ajaran-ajaran agama yang benar dan pemahaman isi al-Quran. Al-Quran sangat penting untuk disosialisasikan pada masyarakat. Karena al-Quran adalah pedoman hidup manusia.

Di pondok Pesantren Darussalam juga mengkaji kitab keislaman klasik yang lebih dikenal dengan istikah Kitab Kuning atau dibeberapa pesantren dikenal pula istilah Kitab Gundul. Disebut kitab kuning karena kertas yang digunakan untuk mencetak kitab tersebut menggunakan kertas yang berwarna kekuning-kuningan. Sedangkan istilah kitab gundul lahir karena teks-teks tulisan Arabnya tanpa menggunakan syakal. Setelah pengkajian tafsir dipelajari pula hadis. Hadis yang dipelajari adalah hadis shohih Bukhari dan hadis Shohih Muslim.

Pensosialisasian al-Quran sangat penting di kalangan masyarakat. Manusia sebagai individu memiliki kecenderungan untuk melakukan aktivitas kebudayaan. Aktivitas kebudayaan pada hakekatnya adalah suatu upaya memuaskan serangkaian dari sejumlah kebutuhan naluri manusia yang berhubungan dengan seluruh kehidupannya. Dalam hal ini, keberagaman manusi mula-mula karena manusia sebagai makhluk ingin memiliki pedoman dalam kehidupan transendentalnya dengan al-Khaliq. Pedoman pokok dalam proses hubungan antara manusia dengan Tuhan, dalam agama Islam itu disebut al-Quran dan as-Sunnah.

Dalam rangka melakukan sosialisasi al-Quran kepada masyarakat, dapat dirumuskan suatu pemikiran bahwa didalam suatu masyarakat perlu ada suatu tuntunan dan keinginan dalam jiwa para 
anggotanya yangf merangsangnya untuk berprilaku sesuai dengan kebutuhan mereka, dan tuntunan serta keinginan itu ditimbulkan dalam pikiran individu warga masyarakat, sehingga mereka memiliki solidaritas dan ikatan yang kuat. Dari sini kemudian diwarnai oleh ajaran-ajaran al-Quran yang dikemas dalam bentuk aktivitas kebudayaan. Berbagai wujud aktivitas kebudayaan itu akan memancarkan nafas-nafas al-Quran yang menyejukan dan menentramkan.

Selain ceramah-ceramah, Irfan Hielmy dalam mensosialisasikan pemikirannya juga lewat seminar-seminar, dan menulis buku. Ia pernah menulis di "Media Dakwah" Depag dan Koran lokal yaitu "Ciamis Post". Sebagai ketua MUI juga secara berangsur-angsur ia melakukan kebijakan dalam masalah syari'at agama Islam.

Irfan Hielmy menganjurkan pada masyarakat untuk selalu berdzikir untuk menciptakan badlah yang tayibah. Karena dengan berdzikir suasana hati menjadi tenang. Kegiatan dzikir ini, harus diawali dari setiap individu. Salah satu cara untuk membiasakan diri untuk berdzikir adalah di sepanjang pinggir jalan di Kabupaten Ciamis dipasang plang yang tertulis dzikir. Plangisasi ini juga merupakan kebijakan Irfan Hielmy di MUI dengan tujuan agar masyarakat penggua jalan membacanya dan berdzikir, bahkan sopirpun setiap kali lewat pasti membacanya. Di Pondok Pesantren Darussalam, ia juga menganjurkan pada para santrinya agar berdzikir 100 kali di pagi dan 100 kali di sore hari. Dengan seringberdzikir, insyaallah Allah SWT akan selalu memberikan apa yang kita inginkan asal dilakukan dengan ikhlas dantulus.

Selain spiritual yang diajarkan, Irfan Hielmy juga mendidik santri secara fisik. Di Pondok Pesantren Darussalam para santri dilatih bela diri, yaitu pencak silat. Hal ini, betujuan untuk mengajarkan pada santri membela diri apabila ia diganggu oleh penjahat. Dengan bekal bela diri ini tuidak diperuntukkan untuk menganiaya yang lemah atau untuk sekedar pamer otot. Kegiatan bela diri ini dilaksanakan setia hari Ahad. 
Irfan Hielmy juga mengadakan sekaligus meneruskan majlis Taklim yang dilakukan oleh ayahnya yaitu pengajian rutin mingguan yang dilaksanakan pada :

1. Hari Rabu, yaitu pengajian yang dikhususkan untuk ibu-ibu yang berasal dari masyarakat sekitarnya.

2. Malam jum'at, yaitu pengajian umum baik bapak-bapak maupun ibu-ibu, remaja maupun anak-anak yang bersala dari semua kalangan.

Irfan Hilemy juga mengadakan pembinaan pada kelompokkelompok pengajian yang berada di bawah koordinsi Pesantren Darussalam. Dengan adanya pengajian ini mampu melahirkan sebuah lembaga pendidikan lainnya. Hal ini dibuktikan dengan Pondok Pesantren Ciloa yang berada di Desa Handapherang dan Pondok Pesantren Cibeunying yang berada di Desa Pusakanegara. Ia juga selalu menghdiri pengajian yang diadakan di berbagai daerah dalam rangka peringatan hari-hari besar Islam, pernikahan, khitanan, dan sebagainya. Hal ini dilakukan oleh Irfan Hielmy ke berbagai daerah seperti Sumedang, Cirebon, Kuningan, dan daerah lainnya.

Hidup dalam masyarakat yang heterogen tidak mudah untuk mengenalkan suatau pemikiran seseorang. Apalagi menghadapi suatu masyarakat yang sangat tradisional. Irfan Hielmy dalam mensosialisasikan pemikirannya banyak sekali menghadapi kendala, baik dari dalam maupun dari luar.

Kendala yang datang dari dalam di antaranya adalah masih banyaknya masyarakat yang tertutup hatinyauntuk mempelajari agama. Agama sangat penting dikenalkan kepada setia orang sejak dini. Pada tahun 1947 masyarakat Kabupaten Ciamis masih sangat kental dengan hal-hal yang berbau mistik. Hal ini bisa mengakibatkan perbuatan syirik. Kendala yang dating dari luar dintaranya adalah pernyataan yang muncul dari masyarakat. Sejak berdirinya Pondik Pesantren Darussalam, masyarakat tidak begitu senang karena dianggap menggangu lungkungan. Presantren sering diejek, diolok-olok bahkan tidak jarang adanya tindak kekerasan. Kekerasan yang terjadi disekitar Pesantren Darussalam ini dibuktikan dengan banyaknya rampok dan 
preman yang menggangu ketenangan santri. Banyaknya rampok di sekitar Pesantren Darussalam ini dikarenakan kondisi daerah Pamalayan yang masih rawan, sehingga membuat para perampok dan preman dapat leluasa bergerak.

Pada tahun 1995 masyarakat mulai sadar akan pentingnya pesantren untuk membina ilmu agama. Masyarakat yang awalnya mengklaim bahwa dengan adanya pesantren mereka merasa diganggu, kini mereka berubah pikiran, justru dengan adanya pesantren masyarakat terbantu dalam segi ekonomi. Di sekitar pesantren mereka membuka warung makan, laundry (jasa cuci pakaian), toko yang menyediakan kebutuhan sehari-hari santri, dan juga angkot yang mengantar para santri. Banyaknya keuntungan yang didapat yang diraih tersebut, mereka akan merasa rugi apabila santri libur dan pulang ke kampung halaman masing-masing.

Melihat kondisi masyarakat Kabupaten Ciamis yang masih tradisional, Irfan Hielmy sangat berhati-hati melakukan dakwahnya. Disinilah kesabarannya diuji. Ia banyak belajar dan membaca, sehingga membuatnya lebih matang dan menjadi seorang kyai yang bijak. Kepada orang yang masih percaya kepada benda-benda keramat, ia tidak langsung mengatakan bahwa orang itu kafir atau syirik. Akan tetapi, ia berusaha dengan penuh kasih sayang memberi pengertian tentang ajaran agama dengan perlahan-lahan.

Kepada para santrinya, Irfan Hielmy juga menjabarkan pemikirannya secara bertahap. Ia selalu menghimbau kepada para santri untuk tidak belajar agama saja tanpa mempelajari ilmu pengetahuan dan teknologi. Ilmu agama dan teknologi harus berjalan seimbang. Pondok Pesantren Darussalam juga mengajak pada masyarakat untuk tidak bermasyarakat saja tanpa memikirkan masalah agama.

Melalui pelajaran di Pondok Pesantren Darussalam kepada santri-santrinya, Irfan Hielmy meminimalkan tradisi-tradisi yang sesat di masyarakat. Dengan melalui santri diharapka akan mampu memberi jalan ynag terang kepada masyarakat dimana para santri berasal. Dari sini akan dilihat hasilnya bahwa pemikiran Irfan Hielmy berpindah secara estafet melaui santri-santrinya. Dengan demikian ide-idenya akan terus hidup dan tidak pernah mati. 
Selama kurang lebih 30 tahun, Irfan Hielmy mengenalkan pemikirannya, barulah masyarakat dapat menerima pemikirannya. Masyarakat berkembang dengan perlahan menjadi masyarakat yang moderat. Banyak daerah yangsudah maju di Kabupaten Ciamis dan tidak lagi menganut kepercayaan-kepercayaan atau meminta-minta ke kuburan. Banyak orang tua yang memasukan anaknya ke Pondok Pesantren Darussalam. Masyarakat berkembang dengan perlahan menjadi masyarakat yang moderat.

\section{KESIMPULAN}

KH. Irfan Hielmy adalah seseorang yang selalu memegang teguh prinsip dalam syari'at agama Islam. Ia mempunyai latar belakang pendidikan dengan memperbanyak belajar sendiri atau otodidak dan belajar dengan ayahnya. Latar belakang keluarga kyai yang selalu memegnag teguh ajaran agama Islam telah membentuk pribadi Irfan Hielmy sebagai sosok yang disegani oleh masyarakat.Irfan Hielmy selalu menekankan kepada para santrinya untuk menuntut ilmu dimanapun agar memiliki wawasan yang luas. Pemikiran-pemikiran Irfan Hielmy yang diterapkan kepada para santri dan masyarakat di Kabupaten Ciamis, mempunyai pengaruh yang besar dalam kehidupan di masyarakat.

\section{DAFTAR PUSTAKA}

Dhofier, Zamakhsyari. Tradisi Pesantren : Study Tentang Pandangan Hidup Kyai. Jakarta : LP3ES, 1992.

Departemen Agama RI. Ensiklopedi Islam, Jilid III. Jakarta : CV. Anda Utama, 2013.

Hielmy, Irfan. Wacana Islam Bahan Telaah Anak Bangsa. Ciamis : PIP Darussalam, 2000.

Hielmy, Irfan. Masayarakat Madani Suatu Ikhtiar dalam Menyongsong Milenium Baru. Ciamis : PIP Darussalam, 1999.

Hielmy, Irfan. Ukhuwah Islamiyah Khazanah Aqidah, Moral, dan Spiritual dari Pesantren. Bandung : Nuansa, 1999.

Hielmy, Irfan. Bunga Rampai Menuju Khairu Ummah. Ciamis : PIP Darussalam, 1994. 
Hielmy, Irfan . Dakwah bi al-Hikmah. Ciamis : PIP Darussalam (1997). Hielmy, Irfan . Kumpulan Materi Pokok Khutbah Jum'at. Ciamis : PIP Darussalam (1997).

Hielmy, Irfan . Masyarakat Madani: Suatu Ikhtiar Dalam Menyongsong Era Milenium Baru. Ciamis : PIP Darussalam (1998.)

Hielmy, Irfan . Pendekatan Keagamaan Dalam Menyelesaikan Masalah Kemasyarakatan. Ciamis : PIP Darussalam (1998).

Hielmy, Irfan . Ukhuwwah Ahlus Sunnah: Khazanah Aqidah, Moral dan Spiritual dari Pesantren .Ciamis : PIP Darussalam (1999)

Hielmy, Irfan . Pesan Moral dari Pesantren .Ciamis : PIP Darussalam (1999). 